\title{
José Bergamin, «La Chimera di Balzac»
}

\section{Marco Stupazzoni}

\section{(2) OpenEdition}

\section{Journals}

\section{Edizione digitale}

URL: https://journals.openedition.org/studifrancesi/26493

DOI: 10.4000/studifrancesi.26493

ISSN: 2427-5856

\section{Editore}

Rosenberg \& Sellier

\section{Edizione cartacea}

Data di pubblicazione: 1 avril 2007

Paginazione: 192

ISSN: 0039-2944

\section{Notizia bibliografica digitale}

Marco Stupazzoni, «José Bergamin, «La Chimera di Balzac»», Studi Francesi [Online], 151 (LI | I) | 2007, online dal 30 novembre 2015, consultato il 23 novembre 2021. URL: http://journals.openedition.org/ studifrancesi/26493 ; DOI: https://doi.org/10.4000/studifrancesi.26493

\section{Questo documento è stato generato automaticamente il 23 novembre 2021.}

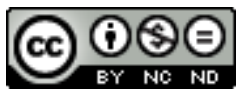

Studi Francesi è distribuita con Licenza Creative Commons Attribuzione - Non commerciale - Non opere derivate 4.0 Internazionale. 


\title{
José Bergamin, «La Chimera di Balzac»
}

\author{
Marco Stupazzoni
}

\section{NOTIZIA}

JOSÉ BERGAMIN, «La Chimera di Balzac», in La Bellezza e le tenebre. Nei labirinti della parola poetica, traduzione di Andrea FANTINI, Milano, Medusa, «Le porpore», 12, 2005, pp. 111-114.

1 L'assoluta modernità dell'universo narrativo di Balzac risiede nel fatto di porsi come «puro mondo del romanzesco più autentico» (p.114), come un'idea ispirata da un misterioso volto di donna che, come una creatura chimerica, afferra la mano dello scrittore e lo conduce verso fantastici cieli. 